\title{
Fighting the smuggling of strategically important resources for environmental safety ensuring
}

\author{
Vladislava Zaigraeva ${ }^{1, *}$ \\ ${ }^{1}$ RUDN University, 6, Miklouho-Maclay str., 117198, Moscow, Russia
}

\begin{abstract}
The international illegal trade of rare flora and fauna objects has long been an acute international issue. At the same time, a significant volume of smuggled rare species of animals and plants falls on Russian Federation. In order to counter criminal encroachments against rare and endangered species of animals and aquatic biological resources, amendments were made to the Russian criminal legislation, including Article 226.1. of Criminal Code of Russian Federation, in accordance with which criminal liability is established for the smuggling of especially valuable wild animals and aquatic biological resources listed in the Red Book of Russian Federation and (or) protected by international treaties of Russian Federation. At the same time, the imperfection of legal norms governing liability for smuggling significantly reduces the level of their protection. These circumstances require constant improvement of measures to counter smuggling, including criminal law improvement.
\end{abstract}

\section{Introduction}

In the conditions of free movement of a huge number of various categories of goods and resources across state and customs borders, due to the liberalization of foreign economic activity and the intensive development of integration processes, environmental issues acquire special relevance.

We share the position of individual authors that smuggling is a threat in every country [1]. The processes of globalization lead to the free movement of goods outside the customs border by hiding them from customs control, which poses a significant threat to the economic security of the state and requires a search for measures to counter the smuggling of goods [2].

Often, the forms of smuggling and its profitability are determined not by the perfection of the law, their inconsistent application and differences in different areas of regulation [3], as well as by the unregulated activities of law enforcement agencies to identify and investigate customs offenses [4].

At the same time, effective achievement of goals for the suppression of crime largely depends on the construction of a system for implementation of norms of law [5], the accuracy of the legislators' formulation of dispositions of criminal law norms [6]. Some

${ }^{*}$ Corresponding author: customs.v.k@gmail.com 
authors give a high role in suppressing smuggling to forensic means and methods [7].

An important role in the protection of the environment, protection of flora and fauna is played by the customs authorities, whose functions include identifying and suppressing the smuggling of strategically important goods and resources. Strategic goods and resources include a large number of "environmental goods" that are the country's national wealth such as timber, oil and oil products, precious metals, sturgeon meat, amber, flora and fauna, ozone-depleting substances, furs and others.

The smuggling of such goods and resources causes irreparable damage to the country's environmental safety and the depletion of its national reserves. All this requires their special protection, including criminal law. As T.G. Lepina noted, "in some countries, certain types of smuggling are classified as crimes that infringe on the safety of the environment, for example, San Marino and the Federal Republic of Germany" [8].

\section{Methods}

The methodological basis of the scientific article is made up of a set of methods and techniques of scientific knowledge inherent in the jurisprudence. In particular, the study used a logical method (when presenting an article, formulating results and proposals), comparative legal (when analyzing regulatory legal acts), statistical (when analyzing data on the number of crimes committed in relation to strategically important goods and resources).

In the legal literature, works of such scientists as Yu.I. Suchkov, S.N. Lyapustin, A.V. Gryaznov, T.A. Dikanova are devoted to the issues of fighting the smuggling of ecological goods, environmental protection, and counteracting the illegal movement of especially valuable wild animals and plants. Also, certain issues of ensuring environmental safety by customs authorities are highlighted in the works of N.E. Simonov, O.G. Bobrova, V.A. Zhbankov.

\section{Results}

In order to implement Article 226.1 of the Criminal Code of Russian Federation, the subject of the crime of which includes, inter alia, strategically important goods and resources, the Government of Russian Federation issued Decree No. 923 dated September 13, 2012 "On approval of the list of strategically important goods and resources for the purposes of Article 226.1 Of the Criminal Code of Russian Federation" (hereinafter - the List of SIG\&R). Details of the qualitative features of all strategically important goods and resources in the context of criminal liability for their smuggling are disclosed in the article of V. Zaigraeva, 2019. Sobre la cuestión de determinar el tema del contrabando de bienes y recursos estratégicamenteimportantes // Revista dilemas contemporáneos: educación, polls [9].

The List of SIG\&R (paragraph 15 of Section II of the List of SIG\&R) includes species of wild flora and fauna falling under the Convention on International Trade in Endangered Species of Wild Fauna and Flora, dated March 3, 1973, or listed in the Red Book of Russian Federation [10].

In accordance with the Federal Law of January 10, 2002 No. 7-FZ "On Environmental Protection", rare or endangered forests and other vegetation, animals and other organisms are subject to special protection.

The species of wild flora and fauna specified in clause 15 of the List of SIG\&R are also included in the Lists of goods prohibited and restricted for movement in the countries of the Eurasian Economic Union: section 2.7. Species of wild fauna and flora subject to the 
Convention on International Trade in Endangered Species of Wild Fauna and Flora of March 3, 1973 (CITES), section 2.8. Rare and endangered species of wild live animals and wild plants included in the red books of the member states of the Eurasian Economic Union.

The export of species of wild flora and fauna from section 2.7 is carried out in accordance with the procedure provided for by the Convention on International Trade in Endangered Species of Wild Fauna and Flora of March 3, 1973; from section 2.8 Regulations on the export from the customs territory of the Eurasian Economic Union of rare and endangered species of wild live animals and wild plants included in the red books of the member states of the Eurasian Economic Union (Appendix 6 to the Lists of goods prohibited and restricted for movement).

A number of names specified in paragraph 15 of the List of SIG\&R coincide with the names specified in the list of especially valuable wild animals and aquatic biological resources belonging to the species included in the Red Book of Russian Federation and (or) protected by international treaties of Russian Federation, for the purposes of Article 226.1 and 258.1 of the Criminal Code of Russian Federation, approved by Decree of the Government of Russian Federation dated October 31, 2013 No. 978 (hereinafter - the CITES List).

The CITES List includes seven species of mammals (Altai mountain sheep, Amur tiger, polar bear, leopard, bison, with the exception of bison-bison hybrids, livestock, saiga, snow leopard); four species of birds (saker falcon, golden eagle, gyrfalcon, peregrine falcon) and eleven species of fish (Amur sturgeon, Atlantic sturgeon, beluga, kaluga, Persian sturgeon, Russian sturgeon, Sakhalin sturgeon, Sakhalin taimen, stellate sturgeon, Siberian sturgeon, thorn). All of them are in the Red Book of Russian Federation or are protected by international treaties signed by Russian Federation.

Thus, when instituting criminal cases against wild flora and fauna under Article 226.1 of the Criminal Code of Russian Federation, law enforcement agencies are obliged to be guided not only by the third section of the List of SIG\&R, but also by the CITES List.

It should be noted that according to the data of the Federal Customs Service, customs authorities in the period from 2012 to 2020.5235 criminal cases were initiated under article 226.1 of the Criminal Code of Russian Federation (of which 6 criminal cases were initiated on the facts of smuggling of strategically important goods and resources in 2012, and 420 criminal cases in 2020). The total value of illegally displaced goods, including strategically important goods and resources, in 2012 - 2020 amounted to about 80 billion rubles. 


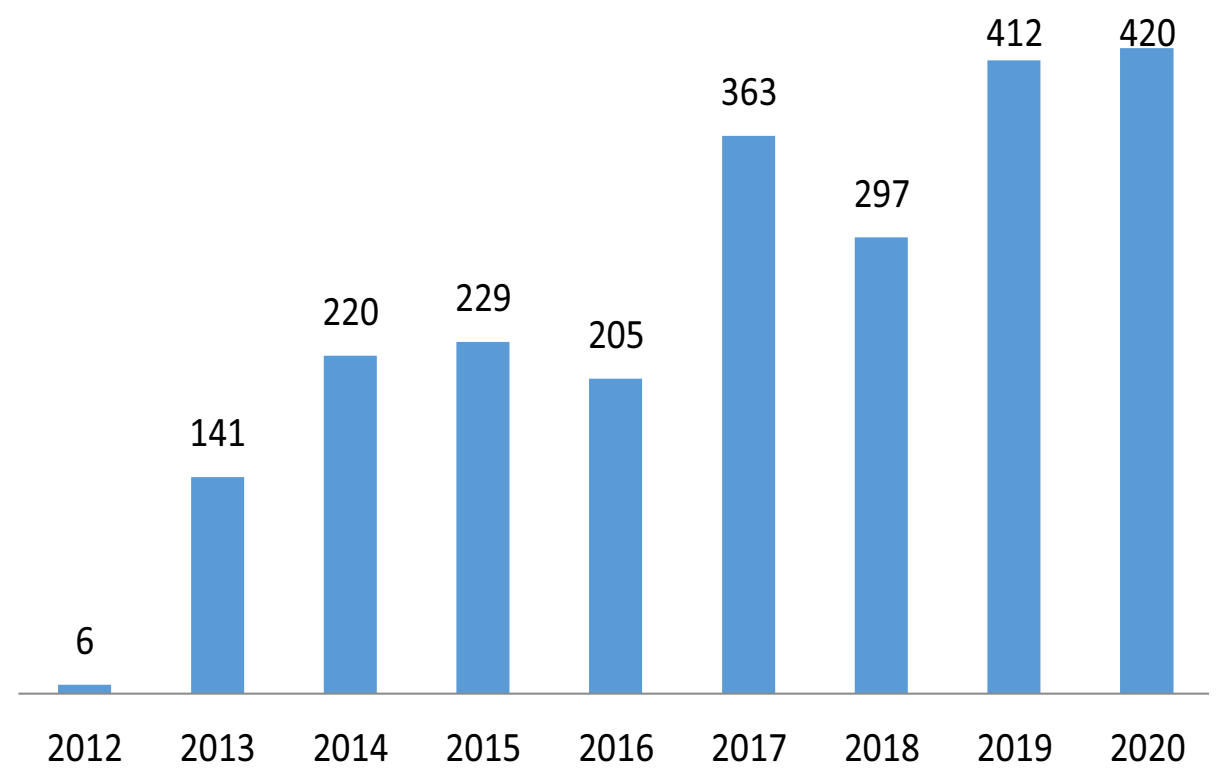

Fig. 1. The number of criminal cases initiated on the facts of smuggling of strategically important goods and resources (Art. 226.1 of the Criminal Code of Russian Federation) [Federal Customs Service].

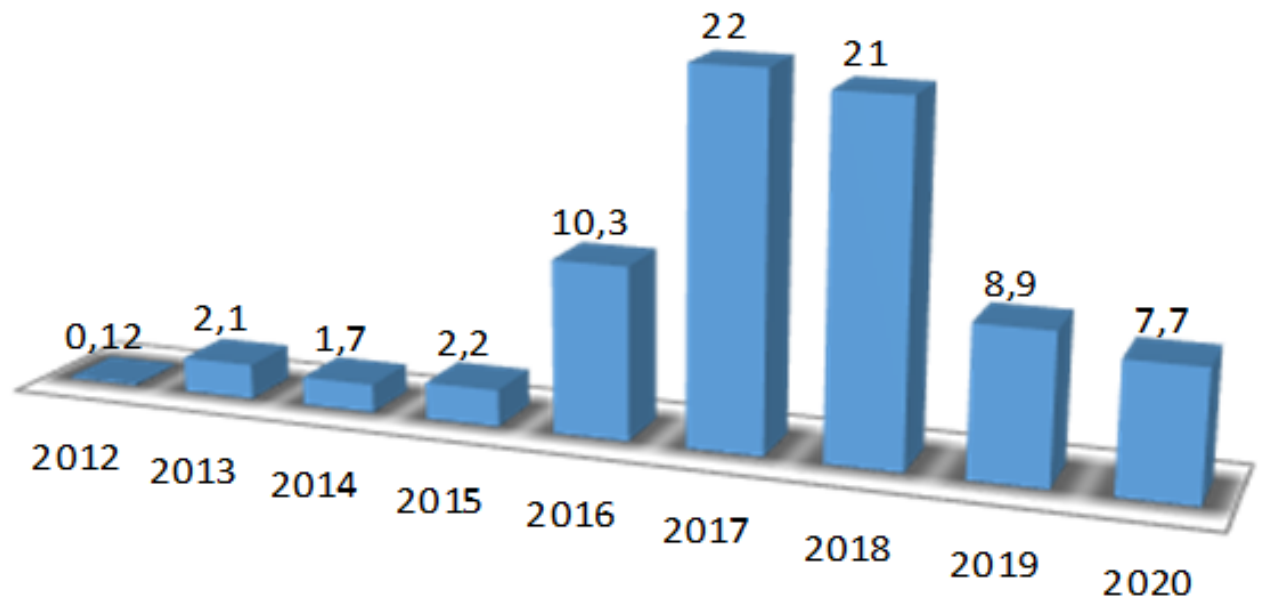

billion rubles

Fig. 2. The total value of illegally displaced goods, includeng strategically important goods and resources, in $2012-2020$ [Federal Customs Service].

Analysis of the List of SIG\&R and the CITES List allows us to talk about gaps and shortcomings of legal regulation.

According to article 226.1 of the Criminal Code of Russian Federation, one of the signs of the subject of smuggling of strategically important goods and resources is their large size, which, in accordance with the note to this article, recognizes their value in excess of one million rubles. An exception was made only for the brown bear (ursusarctos), the Himalayan or white-breasted bear (selenarctosthibetanus), musk deer (moschusspp.), As 
well as timber. For these strategically important goods and resources, a large value is recognized as being in excess of RUB 100 thousand.

A number of names of strategically important resources of flora and fauna indicated in the third section of the List of SIG\&R coincide with the names included in the CITES List, since both are rare and endangered and are listed in the Red Book of Russian Federation or are protected by international treaties of Russian Federation.

In case that the names of especially valuable wild animals and aquatic biological resources, as well as their parts, appear in the CITES List, then for the qualification of acts under Article 226.1 of the Criminal Code of Russian Federation, it will not be required that their value exceeds one million rubles. In the same case, if the names of species of wild flora and fauna falling under the Convention on International Trade in Endangered Species of Wild Fauna and Flora of 03.03.1973, or listed in the Red Book of Russian Federation, do not appear on the CITES List, then for the qualification of acts under Article 226.1 of the Criminal Code of Russian Federation, a large amount will be required, that is, their value must exceed one million rubles.

Analysis of the content of the CITES List allows us to conclude that the solution to the existing problem of determining the value in relation to CITES objects and the Red Book (these items on the territory of Russian Federation are not objects of purchase and sale, that is, they cannot be considered as goods, in this regard, the determination of their value in order to make a decision to initiate a criminal case causes serious difficulties and takes place only in relation to especially valuable wild animals and aquatic biological resources named in it, while in relation to other species of wild fauna and flora, determination of their value (large size) is still required when initiating criminal cases. This situation does not seem to be objective. After all, all of them have an equal status of "rare and endangered".

Such selective (partial) inclusion of wildlife objects in the CITES List may lead to an increase in the illegal turnover of wildlife objects included in the Red Book of Russian Federation, but not included in the specified list.

In this regard, it is doubtful whether it is correct to include the species of wild flora and fauna in the CITES List that fall under the Convention on International Trade in Endangered Species of Wild Fauna and Flora, dated March 3, 1973, or included in the Red Book of Russian Federation.

Based on the above mentioned, it is currently advisable to make the following changes:

In article 226.1 of the Criminal Code of Russian Federation:

In the title, the words "especially valuable wild animals and aquatic biological resources" shall be replaced by the words "rare and endangered objects of fauna and flora".

In the first paragraph of the first part of the word (especially valuable wild animals and aquatic biological resources belonging to the species included in the Red Book of Russian Federation and (or) protected by international treaties of Russian Federation, as well as their parts and derivatives" the words "rare and endangered the disappearance of objects of flora and fauna included in the Red Book of Russian Federation and (or) being objects of international treaties of Russian Federation, their parts or products made from them".

Clause 15 of the List of SIG\&R shall be deleted.

\section{Discussion}

A.V. Kurakin and A.N. Sukharenko suggest "when determining the size of the value of smuggled items, the courts should proceed from the state prices, in other cases, the size is determined on the basis of the market value of goods, with the exception of those moved by an individual for personal use."

T.M. Lopatina believes that "the opinion of supporters of assessing the subject of smuggling at market prices is based, apparently, on the provisions of administrative 
legislation. According to Part 2 of Art. 27.11 of the Administrative Code, the value of seized items is determined on the basis of state regulated prices. In other cases, the value of the seized items is determined on the basis of their market value. The customs value is used for seized goods for personal use, transported by individuals across the customs border of the Customs Union."

According to the position of the FCS of Russia, "the cost of illegally moved strategically important goods and resources when they are exported from the customs territory of the Eurasian Economic Union, as a rule, is determined according to the contract price of these goods. In the event that the law enforcement officer does not have data on the contract price or there is evidence that it is clearly underestimated relative to the market price of similar goods in the domestic market of the Eurasian Economic Union, the cost of these goods is determined by expert means (the contract price of exported goods, as a rule, must exceed the market price). the price of these goods on the domestic market, since the indicated price of goods does not include additional costs in connection with the export of goods outside the customs territory of the Eurasian Economic Union).

The cost of illegally moved strategically important goods and resources when imported into the customs territory of the Eurasian Economic Union is determined by expert advice or using special knowledge of specialists based on the market price for similar goods in the internal market of the Eurasian Economic Union. Other investigative actions may also be carried out to determine or clarify the value of such goods in the domestic market (seizure of documents: invoices, payment orders, contracts related to the sale by offenders of such goods in the domestic market after their illegal import into the customs territory of the Eurasian Economic Union, with the reflection of information about the price of the goods in these documents).

At the same time, under the internal market, if we consider the situation with the use of economic categories, when importing goods into the customs territory of the Eurasian Economic Union, we mean the area where the actual recipient of the goods is located, and when exporting - the area where the sender of the goods is located."

With regard to imported objects of flora and fauna, included in the Red Book of Russian Federation, V.N. Kraeva proposes "in connection with the actual absence of appropriate prices to determine the amount of damage to apply the appropriate rates and methods."

N.V. Kraev, when considering the criteria for differentiating criminal offenses under Articles 226.1 and 258.1 of the Criminal Code of Russian Federation and administrative offenses for especially valuable wild animals, according to species listed in the Red Book of Russian Federation and (or) protected by international treaties of Russian Federation, also notes that "to assess the size of the damage (calculating the cost of contraband), the rates of the corresponding rates and methods can be applied, in particular, the Methodology for calculating the amount of damage caused to objects of the animal world, listed in the Red Book of Russian Federation, the Methodology for calculating the amount of damage caused to hunting resources, etc."

The difference between the points of view presented, in our opinion, confirms the inadmissibility of evaluating rare objects of the animal and plant world in monetary terms and the need to establish criminal liability for their smuggling, regardless of the cost.

\section{Conclusion}

At the present stage, the smuggling of strategically important goods and resources poses a huge threat to the environment in terms of disappearance of rare objects of flora and fauna.

The proposals presented in the framework of our study for improving the criminal norm providing for liability for the smuggling of strategically important goods and resources will make it possible to prosecute persons who illegally move across the state and customs 
borders any rare and endangered objects of animal and plant life. included in the Red Book of Russian Federation and (or) being objects of international treaties of Russian Federation regardless of their value, which will solve the current problem of determining the value when initiating criminal cases, as well as the exclusion of two lists in relation to rare and endangered objects of the Red books of Russian Federation, which will exclude the possibility (risk) of an increase in the illegal turnover of wildlife objects included in the List of SIG\&R, but not included in the CITES List.

\section{References}

1. A. Kulish, O. Yunin, O. Us, I. Shapovalova, Journal of entrepreneurship and sustainability issues (2021) https: // doi: 10.9770 / jesi.2021.8.3 (25)

2. N. Andriichenko, O. Reznik, V. Tkachenko et al, REICE Revista Electrónica de Investigación en Ciencias Económicas (2020) https: // doi: 10.5377 / reice.v8i15.9974

3. P. Kemp, R. Galemba, Illicit Trade and Smuggling (2020) https: // doi: 10.1093 / obo / 9780199743292-0295

4. Z. Ibragimov, K. Kapsalyamov, S. Kapsalyamova, Procedia Computer Science (2019) https://doi.org/10.1016/j.procs.2019.01.167

5. A. Albov, V. Batyukova, E. Kobzeva, N. Ponomareva, Cuestiones Políticas (2021) https: // doi: 10.46398 / cuestpol.3968.51

6. I.V. Lozinsky, Bulletin of the Tomsk State University 417, 203-209 (2017) DOI: $10.17223 / 15617793 / 417 / 29$

7. G. Usova, I. Malykhin, Actual problems of Russian law (2020) https://doi.org/10.17803/1994-1471.2020.121.12.149-156

8. T.G. Lepina, Bulletin of Tomsk State University 454, 226-232 (2020) https: // doi: 10.17223 / 15617793/454/28

9. V. Zaigraeva, Revista dilemmas contemporáneos: educación, política y valores (2019) https://doi.org/10.46377/dilemas.v31i1.1024

10. Collection of existing treaties, agreements and conventions concluded by the USSR with foreign states. Issue XXXII (M., 1978) 